\title{
RENTAL AND MANAGEMENT POLICY OF MUNICIPAL RESIDENTIAL BUILDINGS: HOUSING POLICY. CASE STUDY OF RIGA (PART ONE)
}

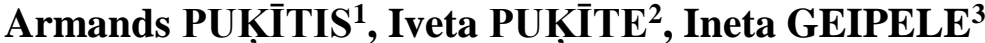 \\ ${ }^{1}$ Rīgas Pilsētbūvnieks (Ltd.), Latvia \\ ${ }^{2,3}$ Riga Technical University, Latvia \\ Corresponding author e-mail: iveta.pukite@rtu.lv
}

\begin{abstract}
The present scientific article is the first part of two publications, where the authors obtain results from the scientific research for municipal residential property legal aspects and housing policy, as well as risks in the maintenance of the housing stock. To ensure the fulfillment of the functions prescribed by law in relation to the provision of living space, each municipality owns a number of rental apartments. Some municipalities even build special dwellings aimed to fulfil this function. Housing management involves the implementation of a specific process prescribed by both the law and the principles of good governance. However, all management processes are subject to risks that can endanger the implementation of the entire management process. To ensure efficient and high-quality maintenance of the management process, risk assessment is required. In order to successfully implement all these activities, first of all, there is a need for a legal framework that will stipulate the obligations, responsibilities, rights of the persons involved, as well as a series of measures that determine the actions to be taken to ensure the successful maintenance of the housing stock. The aim of the article is to investigate and analyse the regulation of the rent of the legal relations of the municipal property that is used as rental apartments, the management processes of municipal residential property and their compliance with regulatory enactments, as well as to define risks that prevent the efficient and high-quality maintenance of the housing stock.
\end{abstract}

Keywords: Municipal housing policy, real estate management, residential rental property.

\section{INTRODUCTION}

In the scientific community, the availability of housing is considered to be the most important social element of sustainable development in the country, which is one of the most significant dimensions. The topicality of the research is reinforced by the inclusion of the dwelling in the group of the basic needs of each individual. Under conditions of a regulated market economy, it is necessary to create preconditions for making housing affordable to as many people as possible in each country and within a reasonable time period. Otherwise, the state should improve 
the living conditions of people whose affordability of housing has become an unattainable goal in the medium to long term (Vanags, 2015).

The housing policy of any country is closely linked to the overall national policy of the country, the welfare of its inhabitants, as well as reduced social isolation and, therefore, characterises the development of the country. Systematisation of the factors influencing the functioning of the real estate market is of great importance to identify the factors and patterns and trends of their influence (Geipele, I., Geipele, S., Stāmure, I., 2013).

The EU's and global practice combines a variety of social housing rent (lease) shape of real property whose owners and/or managers are organisations (national or local authorities), non-commercial institutions (non-profit), or a combination thereof, which has non-commercial purpose - as a rule, associated with access to housing for all segments of the population (Stāmure \& Geipele, 2013).

All countries aim to improve housing conditions for their citizens. Social housing is at the crux of this tension (Scanlon, Whitehead, \& Arrigoitia, 2014).

The municipalities lacking housing stock are entitled to think about housing construction. This is an urgent issue in the city of Riga. On 1 January 2017, Riga Municipality had 3800 people waiting in line for the rental of residential dwelling (Riga Counsil, 2017).

Topicality of the research: To ensure fulfillment of the functions prescribed by law in relation to the provision of living space, each municipality owns a number of rental apartments. Some municipalities even build special dwellings aimed to fulfil this function. Housing management involves the implementation of a specific process prescribed by both the law and the principles of good governance. However, all management processes are subject to risks that can endanger the implementation of the entire management process. To ensure efficient and high-quality maintenance of the management process, risk assessment is required. In order to successfully implement all these activities, first of all, there is a need for a legal framework that will stipulate the obligations, responsibilities, rights of the persons involved, as well as a series of measures that determine the actions to be taken to ensure the successful maintenance of the housing stock.

In order to ensure the high-quality and professional construction of residential buildings and other real estate objects, as well as to promote customer satisfaction with the management and administration of residential buildings, it is necessary to follow a number of different basic principles of operation, which include the fulfillment of the requirements specified in the external regulatory documents, the implementation of measures related to the renovation of buildings, including energy efficiency measures, by carrying out subsequent regular supervision of buildings in order to identify the discrepancies in time and ensure the construction of the structures in accordance with the specified quality requirements and deadlines, as well as to provide public utilities to the tenants of the residential buildings and, without undue delay, carry out the necessary work to prevent accidents and their consequences related to engineering and technical system failure.

The operation of a multi-apartment residential building as a process involves the fulfillment of various specific tasks that are interconnected and aimed at achieving one objective, taking into account a generally known fact that the 
operation of an object is "the lawful use of any physical object in accordance with the purpose of its use for a definite benefit" (Joksts, Girgensone, \& Mihailovs, 2016).

The object of the present research is the management of municipal residential rental property, and the subject of the research is the processes and risks of residential rental property management.

The aim of the article is to investigate and analyse the regulation of the rent of the legal relations of the municipal property that is used as rental apartments, the management processes of municipal residential property and their compliance with regulatory enactments, as well as to define risks that prevent the efficient and highquality maintenance of the housing stock.

To achieve the aim of the article, the following tasks are put forward:

1) to study and analyse the regulatory enactments regarding the rent ratio and the residential property management sector;

2) to clarify housing policy in the Municipal Rental Housing Sector;

3) to explore social housing aspects.

The subject of the current research is problems and risks in rental housing field. The research object is municipal residential property.

Limitations of the research are as follows:

1) the research covers the period of 2012-2016;

2) the management process of rental property of the municipality of Riga is investigated, and risks are assessed.

Within the framework of the research, the authors have used the following methods: a descriptive method, summarising the information and taking into account the scientific literature review, the statistical and analytical methods, which involve a detailed assessment of legal processes, by characterising the current situation and assessing the risks that can affect the process changes in the future.

The laws and regulations of the Republic of Latvia, scientific and professional literature, and the data of the Central Statistical Bureau and the Ministry of Economics of the Republic of Latvia have been used in the present research.

\section{LEGAL FRAMEWORK OF RENTAL HOUSING}

The origins of the contract as the institution of civil law are traced back to ancient times, and the attention of researchers in legal history is mainly attracted to the formation and development of contracts in ancient Rome, although no one can rule out the use of contracts in the earlier period and in another part of the world (Torgāns, 2014).However, on the basis of the information available, one of the earliest types of contracts wastherentalcontract that was already known in ancient Rome, where it was assumed that the rentalcontract was an agreement according to which one party (the locator) assumed the obligation to give the other party (the conductor) the use of his object for some time, but the conductor on his part consented to pay renumeration (merces) and, upon expiry of the use, to return the property to the locatorwithout damage to the property (Kalniņš, 1997).

According to the Civil Law, a lease or rental contract is a contract pursuant to which one party grants or promises the other party the use of some property for a 
certain lease or rent payment. A contract that grants the use of a fruit-bearing property in order to gain fruit thereof is a lease, but any other contract-granting use is a rental contract (Legislation of the Republic of Latvia, 1937, Section 2112).

The focus on public housing is important, since in Latvia, municipal institutions are the major social landlords. Rent structures are not sensitive to demand or quality of housing services, and allocation decisions rely on bureaucratic processes (Tsenkova \& Turner, 2010).

The basic features of a rental contract stipulated in Section 2112 of the Civil Law are also specified in Section 2 of Chapter 1 of the Law "On Residential Tenancy", which states: "Rental of residential space shall be the transfer of the right to use a residential space to another person for a charge".

The right to use residential space may be transferred to another person by the owner of the residential space, the possessor, as well as a municipality if such municipality has obtained the relevant residential space for use on a legal basis in accordance with the Law "On Assistance in Solving Apartment Matters".

A lease or rental contract, in terms of the classification of legal transactions, is a bilateral transaction since it requires the operation of two parties to conclude it. The assignment (surrender) of property or its promise does not make a contract since it is also necessary to recieve acceptance of the property or the respective promise from the other party. In the process of concluding a contract, it is necessary to take into account manifestation of the will of the both parties. Moreover, a lease or rental contract is a casual transaction, as the basis for its conclusion is evident from the content of the transaction. The essential components of this contract are the subject matter and fee (Legislation of the Republic of Latvia, 1937, Section 2113). The latter refers to a lease or rental contract as a remuneration transaction.

When a transaction between two parties is made, it is important for both parties involved in the transaction to enter into a written agreement in order to avoid potential disagreements in the future. This condition should certainly be observed in the rental relationship.

A contract enforceable by law is a legally binding agreement. Section 1588 of the Civil Law stipulates that "one party may not withdraw from a contract without the consent of the other party, even if the latter fails to perform it and due to the failure to perform it". Likewise, Section 1587 of the Civil Code states that "a contract legally entered into shall impose on a contracting party a duty to perform that which was promised, and neither the exceptional difficulty of the transaction, nor difficulties in performance arising later, shall give the right to one party to withdraw from the contract, even if the other party is compensated for losses" (Legislation of the Republic of Latvia, 1937).

However, the practice shows that there are situations when there is a need to change the terms of a lease or rental contract or to terminate the contract that cannot be unilaterally carried out. If one party does not agree to the amendments to a lease or rental contract, the other party must take a legal action regarding the termination of a lease or rental contract.

One of the major problems inherent in the rental relationship is the tenant's nonpayment for the services and the problems of the renter with the termination of the contract and the recovery of losses caused thereby. 
Section 13 of the Law "On Residential Tenancy" stipulates that all disputes arising from the amendment of a lease or rental contract shall be settled by the court (Legislation of the Republic of Latvia, 1993, Section 13). At present, the regulation of rental relationship in Latvia does not promote the development of rental housing stock in the country. Therefore, to solve the situation, a new draft law is being drawn up. The Law "On Residential Tenancy" will envisage the possibility of undisputed compulsory execution of obligations in the following cases (Ministry of Economics of the Republic of Latvia, 2017):

1) the tenant's obligation is to leave the rented residential space due to the expiry of the contract;

2) the tenant's obligation is to leave the rented residential space if the rented property is expropriated in the course of the rental contract that is not registered in the Land Register;

3) the tenant's obligation is to leave the rented residential space if there is a rental debt.

The authors believe that the opportunity to resolve disputes without court proceedings will reduce the burden on the courts, which will enable the courts to deal more quickly with those disputes concerning rent, where judicial interference is required, as well as increase the volume of investment, since at present when the investor is willing to invest in Latvia and is faced with the fact that the rental property is involved in lengthy court proceedings, the investor is not willing anymore to engage in these court proceedings or wait until these proceedings finish and investors instead of investing in Latvia are considering alternative options in neighbouring countries.

According to Latvian experts, in order to resolve the rental relations, it is always necessary to conclude a written lease or rental contract, which has the following advantages:

1) the document is legally correct;

2) both parties are explained the content of the contract, and the rights and obligations of both parties;

3 ) the contract provides a legal guarantee to both parties (Legislation of the Republic of Latvia, 2009.)

A conclusion - in order to avoid possible problems, it is necessary to conclude a written lease or rentalcontract, which also needs to be certified by a notary.

\section{HOUSING POLICY IN THE MUNICIPAL RENTAL HOUSING SECTOR}

The aim of the housing policy is to promote the quality and affordability of housing, providing a regulatory basis for the efficient management of residential buildings, promoting the creation of rental housing stock in municipalities and supporting energy-efficiency measures in residential buildings (Ministry of Economics of the republic of Latvia, 2017).

According to Eurostat data, in 2013, $41.1 \%$ of the population of the 28 European Union (EU) Member States lived in apartments, slightly more than one third $(34.0 \%)$ - in detached houses, and $24.1 \%$ - in twin houses. The largest 
proportion of people living in apartments in the EU Member States was found in Spain (65.4\%), Latvia (65.3\%), and Estonia (63.8\%). One of the main factors to be taken into account when assessing the quality of the conditions in the dwelling is the provision of sufficient space. The overpopulation indicator provides information on the proportion of people living in an overcrowded dwelling, which is determined by the number of rooms available in the household, the number of household members as well as their age and family status. According to statistics, in 2013, $17.3 \%$ of the population of the 28 EU Member States lived in overpopulated dwellings; the highest overpopulation indicators among the EU Member States were registered in Romania (52.9\%), Hungary (45.7\%), Poland $(44.8 \%)$, Bulgaria (44.2\%), and Latvia (38\%) (Ministry of Economics of the Republic of Latvia, 2017).

To develop a more complete housing quality indicator, in addition to overpopulation, several aspects of poor living conditions are taken into account, such as the absence of a bathroom or a toilet, a leaky roof or a dwelling that is too dark. A very poor standard of living is defined as the proportion of people living in a dwelling that is considered to be overpopulated and at the same time exhibits at least one of the above-mentioned aspects of poor living conditions. In 2013, a total of $5.2 \%$ of the population of the 28 EU Member States were faced with very poor living conditions. The highest proportion of people who have very bad living conditions is in Hungary - $17.6 \%$; this indicator is also very high in Latvia (16\%). Thus, in general, the housing stock in Latvia is outdated, with inadequate amenities, overpopulated (Ministry of Economics of the Republic of Latvia, 2017).

The State Audit Office in its 2016 report indicated that there was no valid housing policy planning document in Latvia; the last housing policy planning document was approved in 1996 and lost its relevance; regulatory enactments were often amended.

In accordance with Paragraph 9 of Section 15 of the Law "On Local Governments", one of the autonomous functions of the municipality is to provide assistance in resolving issues regarding housing. The provision of well-equipped apartments to the disadvantaged inhabitants of Riga is one of the functions and priorities of municipalities. Municipalities lacking housing stock are entitled to think about housing construction. This is an urgent issue in the city of Riga. On 1 January 2017, Riga Municipality had 3800 people waiting in line for rental of residential dwelling.

Municipalities acquire apartments in several ways: apartments that were transferred or not privatised; purchase of apartments from the state (escheat); auctions; construction of residential buildings, as well as buying apartments in other municipalities (for example, Riga City Council has apartments in Pieriga - Olaine, Salaspils, Ādaži, Sigulda).

In Riga, when organising the construction of municipal rental or social housing, both the Construction Law and Riga Territory Planning for 2006-2018 are taken into account.

Chapter 2 "Requirements for the Planning and Use of All Territories" of the Cabinet Regulation No. 240 "General Regulations for the Planning, Use and Building of the Teritory" consolidates the principle of equal opportunities and the 
principle of universal design, requiring the planning of the territory and the creation of the environment in such a way that it is equally accessible to all members of the community. The accessibility of the environment and, in particular, the principle of universal design are especially topical in municipal apartments, because they are home to different types of people, both elderly people and people with special needs (General Provisions on Planning, Use and Building of Territory, Section 4).

Persons who have the right to rental property of the municipality are: lowincome persons, children who are left without parental care as well as orphans, tenants of denationalised buildings, persons released from detention centers, and persons with disabilities of group 1 or 2 .

The social apartment is different from the municipal rental apartment in terms of rent payment and fees for utilities. Low-income persons (families) may qualify for a social apartment owned by a municipality.

The municipalities' assistance in resolving the issue regarding housing is stipulated by the Law "On Assistance in Solving Apartment Matters", the Law "On Social Apartments and Social Housing", the Law "On Residential Tenancy", and appropriate municipality binding regulations, according to which the municipality can (and many do) identify a wider range of supported people.

However, both in the laws and in the relevant binding regulations of municipalities, one of the main conditions for receiving assistance is the status of a low-income person. Since the status of a low-income person is granted for a certain period of time, Section 11 of Chapter 2 of the Law "On Social Apartments and Social Housing" stipulates that the social apartment rental contract shall be concluded for a period not exceeding six months and shall be renewed, if after the expiry of the contract the tenant and his family members have not lost the right to rent a social apartment.

However, the apartaments to which a social housing status is not granted are rented for a longer period of time. Although Section 6 of the Law "On Residential Tenancy" stipulates that a rental contract may be entered into on the basis of an agreement among the parties (either for a specific period of time, or without indicating the duration of the agreement), in recent years the municipalities have been concluding contracts for a specified period of time and then, if necessary, extend them.

For example, in binding regulations No. 80 of Riga City Council as of 15 June 2010 "On the Procedure for Registration and Assistance in Solving Apartment Matters", it is stipulated that the municipal housing units are rented for two years, including an obligation stipulating the tenant's right to request extension of the contract if the tenant fulfills the terms and conditions of the rental contract (Dārzina, 2013).

As of 31 December 2016, the municipal property in general has 49895 apartments that are used as rental apartments (Table 1). Of all the residential properties in the whole Riga Municipality, properties are 21 percent of apartments. It can be concluded that $1 / 5$ of all rental apartments are owned by Riga Municipality (Ministry of Economics of the Republic of Latvia, 2016). 
Table 1. The number of municipal apartments (Ministry of Economics of the Republic of Latvia, 2016)

\begin{tabular}{|c|c|c|c|c|}
\hline & \multicolumn{4}{|c|}{ The number of municipal apartments } \\
\hline & & \multicolumn{3}{|c|}{ including } \\
\hline & Total & $\begin{array}{c}\text { privatized } \\
\text { apartments (the } \\
\text { apartments renting } \\
\text { of which is not } \\
\text { related to assistance } \\
\text { in solving housing } \\
\text { issues) } \\
\end{array}$ & $\begin{array}{l}\text { the number of } \\
\text { apartments that } \\
\text { are rented to } \\
\text { provide assistance } \\
\text { in solving housing } \\
\text { issues }\end{array}$ & $\begin{array}{c}\text { unrented } \\
\text { apartments }\end{array}$ \\
\hline $\begin{array}{l}\text { Municipalities } \\
\text { TOTAL: }\end{array}$ & 49895 & 35930 & 13312 & 3239 \\
\hline Riga & 13618 & 9266 & 609 & 226 \\
\hline Daugavpils city & 4084 & 2107 & 1977 & 0 \\
\hline Jelgava city & 1236 & 496 & 636 & 104 \\
\hline Jekabpils city & 2128 & 1104 & 64 & 46 \\
\hline Jurmala city & 1095 & 136 & 918 & 41 \\
\hline Liepaja city & 4776 & 0 & 219 & 160 \\
\hline Rezekne city & 1007 & 890 & 74 & 43 \\
\hline Valmiera city & 411 & 197 & 183 & 31 \\
\hline Ventspils city & 2727 & 2666 & 61 & 0 \\
\hline
\end{tabular}

To fulfill the terms and conditions of the rental contract also means paying for utilities and apartment maintenance costs. Under the pretext of a lack of money, social housing tenants cannot but pay for utilities and cannot collect debts. If a family meets a low-income family status and is unable to pay for an apartment, it can apply for a housing allowance (Dārziņa, 2013).

The problem of rental of residential space has also been studied by the Latvian Association of Local and Regional Governments. According to the advisor to the Latvian Association of Local and Regional Governments Aino Salmiňš (2016), the housing rental policy is currently aimed only at providing assistance to the lowincome and social risk families. It is not oriented to development, or to business. At the same time, it is stated that the housing policy should not only be social because the development of human resources is not a social issue. The development of the territory is planned by the state, the municipality, but the development of the housing stock is regulated by the market. Aino Salmiņš distinguished the following market failures: 
1) the market is not capable of satisfying the public needs in a particular sector;

2) in Latvia, the social rental sector is excluded from the common housing rental market and the state does not seek to influence 'private sector prices';

3) there is the housing market only in large cities and certain regional centers;

4) in districts, the demand for apartments with partial comfort exceeds supply;

5) in many municipalities of Latvia, there is a shortage of living space and municipalities are forced to cover heating and management costs for empty apartments instead of the managers of the house (Salmiňš, 2016).

In order to improve the legal framework for the rental of residential propety, a working group was set up at the beginning of 2016 to draw up the draft law on Residential Tenancy. The goal is to promote affordable housing, ensuring a fair balance between the interests of the renter and the tenant. The working group is composed of the representatives of state institutions in order to agree on a common view on the legal framework. After discussions among the state institutions about the draft law, it will be coordinated with the stakeholders - the tenant and the companies representing the renters. It is planned that the draft law could be submitted for public discussion at the end of this summer (Ministry of Economics of the Republic of Latvia, 2016).

The main issues of concern:

1) registration of rental contracts in the Land Register, ensuring greater protection of the renter upon expiry of the rental contract, as well as in cases when the owner changes the living space;

2) the rights and obligations of the tenant and his/her family members;

3) cases where the rental contract can be terminated;

4) transitional regulation for dealing with existing situations in practice.

It is currently intended not to divide the services into basic and ancillary services, as well as it is envisaged not to include in the legal framework for rental of residential property the procedural issues related to tenant eviction (Ministry of Economics of the Republic of Latvia, 2016).

In the area of housing management, the legislator has issued the "Law on Management of Residential Housing". The law defines the principles of the management of a residential building, the relations, rights, obligations and responsibilities of the persons involved in the management process of residential buildings, as well as the competence of the state and municipalities in this area (Law on Management of Residential Housing, 2009). The law applies to the management of all residential buildings, regardless of the owner of a residential building (Law on Management of Residential Housing, 2009). Starting from 1 July 2016, a standard VAT rate of $21 \%$ is applied to the residential building management service.

Residential building management is a specific service. It includes a specific way of enforcing property rights, within which all owners jointly undertake residential building management. In cases when a building is owned by a municipality, municipalities may decide to delegate housing management functions to a management company - to set up a special company (for example, in Riga), to delegate these functions to a municipal company that manages privately-owned, privatised residential houses, or to delegate housing management functions to a 
private legal entity (company) selected through public procurement that will manage the housing stock owned by a municipality.

In high-quality communication, the manager is able to present problem situations to the tenants of multi-apartment residential buildings and to offer solutions to owners so that they have the motivation to pay for management services. This is a very important task of the manager.

A quality management service means that all necessary technical, legal and financial measures are taken, as a result of which all functions involved in the management process are fulfilled. High quality of service can have a twofold impact on the company's future operations.

\section{DISCUSSION ABOUT SOCIAL HOUSING}

One of the most important socio-economic issues is the provision of housing stock to all social groups of the population. Housing policy is related to general sector policies, to the welfare of the population, as well as to the reduction of social exclusion, and hence it characterises the country's development as a whole. Thus, Latvia, along with joining the European Union, should also ensure the quality of life of the population to the indicators of the other Member States, including the availability of housing, the quality of construction, as well as the income balance of the inhabitants with the price of housing (Ministry of Economics of the Republic of Latvia, 2008).

The construction and development of social dwellings is part of a common housing policy; therefore, three principles should be observed in the development of this policy both by the state and the municipalities within their territories.

1. Collaboration principle:

- the state and municipalities develop a social housing policy considering that the person

- endeavors to ensure housing himself/herself;

- chooses a place of residence according to his/her income level;

- endeavors to raise the level of his/her own income, as a result, also the level of prosperity.

2. Assistance principle:

- if a person is unable to ensure himself/herself with a dwelling (lowincome or poor), the municipality provides assistance in resolving apartment issues by renting a social dwelling;

- the municipality provides assistance in resolving housing issues by renting a social dwelling until the crisis situation is resolved, i. e., a person has raised his/her income to a level that he/she is able to purchase or rent a dwelling independently, i. e., until the person can afford a dwelling in the real estate market

- if the municipality is not able to perform its autonomous function - to provide assistance to residents in resolving apartment issues by renting a social dwelling, then the state helps the municipality through grants within the budget.' 
3. Integration principle:

- the development of social housing is carried out in such a way that it does not allow for the formation of segregation regions in both densily and least densily populated areas, creating living space as a complex where jobs, social infrastructure, and other services are available (Ministry of Economics of the Republic of Latvia, 2008).

The United Nations Economic Commission for Europe (UNECE) has developed social housing guidelines, offering its vision of housing policy planning in the field of social housing and its relation to other sector policies, including spatial planning, construction, employment, health, and well-being.

According to these guidelines, the social housing strategy should clearly determine the role of the state, the municipalities and the private sector in the development of these dwellings, including assessment of the most effective options and risks of social housing development.

In the EU Member States, social dwellings have several goals:

- to provide appropriate and affordable housing for people who have difficulty in providing themselves with housing;

- to prevent social stratification by person's income in terms of housing choice and distribution of population;

- to promote social integration by providing equal housing conditions for all citizens (Czischke, 2005).

In Europe, there are several possible options as to how to ensure and who ensures social housing for a particular group of people. Responsibility for the provision of this housing sector can be assumed by the state or municipalities, delegating certain tasks to other institutions and maintaining control over their execution, or they may entrust responsibilities to certain specially established organisations (Czischke, 2005). Furthermore, several of these variants can simultaneously function in one country. European countries also attach high importance to the quality management of social dwellings from the perspective of socialisation. Neat and clean environment as well as public order will not create discomfort for the people of this housing stock and create a sense of equality with the tenants of market dwellings in terms of housing quality and environment.

Taking into account the population's solvency tendency and the number of people who are approaching retirement age as well as the already existing demand for social housing, the demand for social housing will not decrease.

\section{Problem: Improvement, technical condition}

The degree of the improvement of social housing is lower than the average indicators of housing stock in Latvia; many dwellings are not connected to the centralised water supply system, while central heating is provided in $55 \%$ of social residential buildings. A possible solution: to identify that the status of a social residential building can be determined for the municipal residential buildings constructed or reconstructed in accordance with the procedure specified in the Construction Law and the General Construction Regulations, as well as in the requirements specified in the Latvian Construction Standard LBN 211-98 "Multi- 
storey Multi-apartment Residential Buildings". It should be incorporated into the Law "On Social Apartments and Social Housing".

The second aspect of this problem is that the level of social housing improvements is not suitable for people with special needs. Existing social residential buildings need to be reconstructed to accommodate people with special needs, and new social residential buildings should be equipped with the equipment necessary for people with special needs.

\section{Problem: Energy efficiency}

Most residential buildings that were granted a social housing status had been built by 1992. They do not meet today's thermal and environmental requirements, taking into account that heat supply systems are morally and technically outdated; no measures have been taken so far to increase heat insulation and save energy resources for social housing.

According to the Cabinet of Ministers (2008), the solution is to provide an accessible co-financing from the EU Structural Funds for the renovation of residential buildings with the aim of "improving energy efficiency in municipal residential buildings". The ERDF co-financing of this activity is $85 \%$, but it should be noted that the municipalities cannot afford the remaining $15 \%$ and, therefore, often do not take this opportunity (Cabinet of Ministers, 2008).

\section{Problem: New housing development (construction, renovation, reconstruction, purchase of apartments)}

Since $99.24 \%$ of apartments have been transferred from the state or municipal housing stock for privatisation (Ministry of Economics of the Republic of Latvia, 2016), municipalities have an insufficient number of dwellings to fulfill their autonomous function - to provide assistance in resolving apartment issues by renting social dwellings to low-income persons, as a result of which municipalities grant a social housing status to separate rooms in apartments or rooms in dormitories (hostels) and the status of a social residential building to a dormitory (hostel) - hence the housing conditions and welfare of the low-income (poor) persons are low compared to the rest of the population. The requirements for the reconstruction of buildings, transforming them into social dwellings, are disproportionately high (they do not differ from commercial buildings and social dwellings).

\section{CONCLUSION}

The need for housing is one of the basic needs of a person. A heated living area in Latvia cannot be a luxury - it is the basis of a person's appropriate living conditions. Almost all the population of cities and districts is directly and indirectly involved in the development of a housing policy. Both in the country and in each municipality there is a large number of residential buildings, which should be efficiently maintained with the goal of increasing their sustainability.

Municipalities should assume so many social responsibilities and provide social assistance that they do not have the means (financial resources) that could be 
allocated to the social housing sector - the development of existing social buildings and the construction of new social residential buildings. The solution could be to grant state subsidies:

1) for the construction of social residential buildings;

2) for the construction of municipal rental buildings;

3) for the joint construction of rental buildings by municipalities and commercial companies;

4) for the rebuilding (reconstruction) of structures owned by the municipality into residential buildings or for the completion of newly built multiapartment buildings (of which construction works have been terminated), or for the renovation of non-rented residential buildings;

5) for the joint rebuilding (reconstruction) of buildings owned by the municipality and commercial companies into residential buildings or for the completion of newly built multi-apartment buildings (of which construction works have been terminated), or for the renovation of non-rented residential buildings;

6) for the purchase of separate apartment property.

Within the framework of the research, the research group has laid the foundation for further research on the social functions and characteristics of the municipality, which justifies the topicality of social problems and the need for further research. In the second part of the research, the authors plan to assess the management process risks of rental property in the municipality of Riga.

\section{REFERENCES}

Cabinet of Ministers. (2008). Noteikumi par darbības programmas "Infrastruktūra un pakalpojumi” papildinājuma 3.4.4.2. aktivitātes "Sociālo dzīvojamo māju siltumnoturības uzlabošanas pasākumi" projektu iesniegumu atlases pirmo kārtu [Regulations on the First Round of Selection of Project Applications for the Action Plan 3.4.4.2 "Improvement of the Thermal Resilience of Social Residential Houses" of the Operational Program "Infrastructure and Services”]. Retrieved from https://likumi.lv/doc.php?id=169403

Czischke, D. (2005). Social Housing in the EU. Time for Legal Certainty for Local Authorities, Social Housing Providers and Millions of Europeans Households. Brussels, CECODHAS.

Dārziņa, L. (2013, March 7). İrnieka un izīrētāja interesēs ìres līgumam jābūt rakstveidā un par to bütu jāzina valstij [In the interests of the tenant and the lessee, the rental agreement must be in writing and should be known to the state]. Retrieved November 9, 2017, from http://www.lvportals.lv/visi/likumi-prakse/254193-irnieka-un-iziretaja-intereses-iresligumam-jabut-rakstveida-un-par-to-butu-jazina-valstij/

Eurostat. (2016). Statistics on housing. Retrieved September 17, 2017, from http://ec.europa.eu/eurostat/statistics-explained/index.php/Housing_statistics/lv

Geipele, I., Geipele, S., \& Stāmure, I. (2013). The System of Social and Economic Factors in the Housing Market. Экономика и управление: вчера, сегодня, завтра [Eсопоту and Management; Yestterday, Today, Tomorrow], 2(3), 39-46. ISSN 2304-4047

Joksts, O., Girgensone, B., \& Mihailovs I. J. (2016). Terminu skaidrojoš̄ $\bar{a}$ vārdn̄̄ca [Glossary]. Civiltiesības. (Lietu tiesības) [Civil Law. (Case law)]. Riga: SIA Drukātava. 230 p.

Kalniņš, V. (1997). Romiešu civiltiesību pamati [The Basics of Roman Civil Law]. Riga: Zvaigzne.

Legislation of the Republic of Latvia. (1937). Civil Law. Fourth part. Retrieved from https://likumi.lv/doc.php?id=90220

Legislation of the Republic of Latvia. (1993). Law on Residential Tenancy. Retrieved from https://likumi.lv/doc.php?id=56863 
Legislation of the Republic of Latvia. (2009). Law on Management of Residential Housing. Retrieved from https://likumi.lv/ta/id/193573-dzivojamo-maju-parvaldisanas-likums

Ministry of Economics of the Republic Latvia. (2008). Concept Project "Concept of Social Housing”. Retrieved from tap.mk.gov.lv/doc/2005/EMKonc_051108.3599.doc

Ministry of Economics of the Republic of Latvia. (2016). Research, statistics. Retrieved October 1, 2017, from https://em.gov.lv/lv/nozares_politika/majokli/petijumi_statistika/

Ministry of Economics of the Republic of Latvia. (2017). Draft Law on Residential Tenancy. Retrieved November 9, 2017, from https://em.gov.lv/files/ministrija/EMlik_070617_ire.doc

Riga Counsil. (2017). Kā saņemt mājokli no pašvaldības? [How to get Housing from Municipality?]. Retrieved October 19, 2017, from https://www.riga.lv/lv/news/ka-sanemt-majokli-nopasvaldibas?9052

Salmiņš, A. (2016). EU housing policy. Retrieved September 29, 2017, from http://ms.lps.lv/wpcontent/uploads/2016/01/ES-valstu-m\%C4\%81jok\%C4\%BCu-politika.pdf

Scanlon, K., Whitehead, C., \& Arrigoitia, M. F. (2014). Social housing in Europe. Wiley. ISBN 9781118412350

Stāmure, I., \& Geipele, S. (2013). Social Housing Amenities in Latvia. In 53. RTU Studentu zinātniskās un tehniskās konferences materiāli, Riga, Latvia, April 1-26, 2013. Riga: RTU Press. (pp. 131). ISBN 9789934103919

Torgāns, K. (2014). Saistību tiesības. Mācību grāmata [Commitment rights. Textbook]. Riga: Court House Agency.

Tsenkova, S., \& Turner, B. (2010). The Future of Social Housing in Eastern Europe: Reforms in Latvia and Ukraine. International Journal of housing policy, 4(2), 133-149. https://doi.org/10.1080/1461671042000269001

Vanags, J. (2015). Functional Relationship between Housing Availability and Creditworthiness of Households in Baltic and the Northern EU Countries. In Proceedings of the 56th International Riga Technical University Conference "Scientific Conference on Economics and Entrepreneurship SCEE'2015”, Riga, Latvia, October 14-17, 2015. Riga: RTU Press. (pp. 216-217). ISBN 9789934827532. ISSN 2256-0866

\section{AUTHORS' SHORT BIOGRAPHIES}

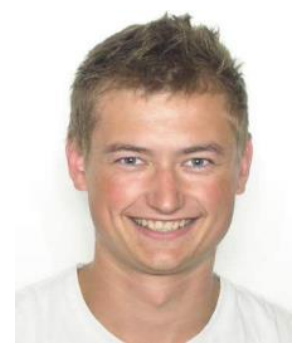

Armands Puķīis, B. sc., studied at the Faculty of Engineering Economics and Management at Riga Technical University (RTU) and received the Bachelor's degree in real estate management. He has 10 years' experience in the field of real estate. At present, he is the Manager of Real Estate at "Rìgas Pilsētbūvnieks" Ltd. His research area is municipal residential building.

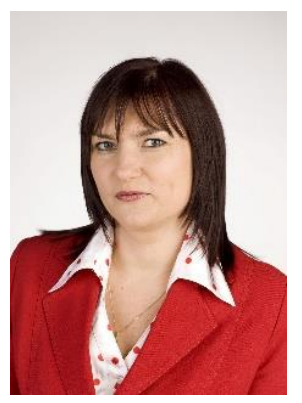

Iveta Pukīte, Mg. sc. ing., a Researcher of the Faculty of Engineering Economics and Management at Riga Technical University (RTU) and a PhD student at RTU. She received the Master's degree in management sciences from the University of Latvia. She is a Lecturer at the College of Law and the Head of Real Estate Management Department at "Ādažu Namsaimnieks" Ltd. I. Puķīte has participated in the international scientific conference "Economic Science for Rural development", Jelgava, Latvia, in the 3rd European interdisciplinary forum "Drivers for Progress in the Global Society", Vilnius, Lithuania, and others. Her research area is the socially responsible housing lifecycle of the management system.

ORCID iD: http://orcid.org/0000-0003-2500-0501 


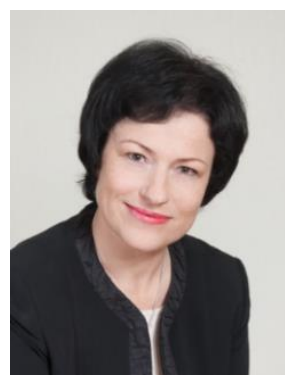

Ineta Geipele is a Professor of the Faculty of Engineering Economics and Management, Director of the Institute of Civil Engineering and Real Estate Economics, the Head of the Department of the Civil Construction and Real Estate Economics and Management at Riga Technical University, Latvia. She improved her professional skills in Austria, Germany, Denmark and the UK. Ineta Geipele is the author and co-author of more than 300 scientific publications. Her current research areas are sustainability development problems of real estate market, construction industry, land use management and institutional economics. Professor Ineta Geipele is an expert of the Latvian Academy of Sciences in Management and Economics Sciences at the Latvian Council of Science, a board member of the FIABCI-Baltic Multinational Chapter and of the Cunfte of the Facility Management of Latvian Housing, and a member of the Latvian Union of Civil Engineers.

ORCID iD: http://orcid.org/0000-0002-2963-087X 